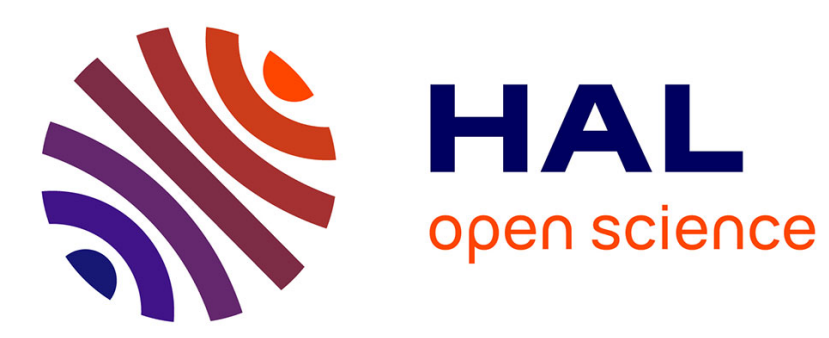

\title{
Primary Student-Teachers' Conceptual Understanding of the Greenhouse Effect: A Mixed Method Study
}

Ilkka Johannes Ratinen

\section{To cite this version:}

Ilkka Johannes Ratinen. Primary Student-Teachers' Conceptual Understanding of the Greenhouse Effect: A Mixed Method Study. International Journal of Science Education, 2011, pp.1. 10.1080/09500693.2011.587845 . hal-00721220

\section{HAL Id: hal-00721220 \\ https://hal.science/hal-00721220}

Submitted on 27 Jul 2012

HAL is a multi-disciplinary open access archive for the deposit and dissemination of scientific research documents, whether they are published or not. The documents may come from teaching and research institutions in France or abroad, or from public or private research centers.
L'archive ouverte pluridisciplinaire HAL, est destinée au dépôt et à la diffusion de documents scientifiques de niveau recherche, publiés ou non, émanant des établissements d'enseignement et de recherche français ou étrangers, des laboratoires publics ou privés. 


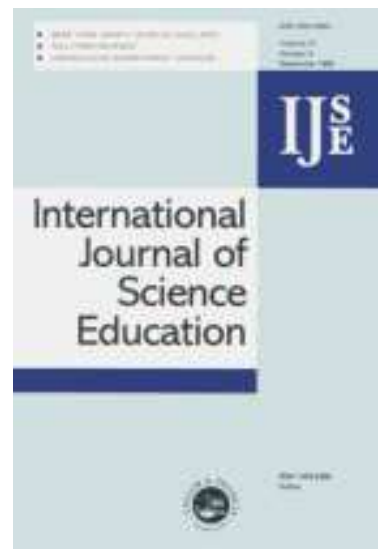

\section{Primary Student-Teachers' Conceptual Understanding of the Greenhouse Effect: A Mixed Method Study}

\begin{tabular}{|r|l|}
\hline Journal: & International Journal of Science Education \\
\hline Manuscript ID: & TSED-2009-0114.R4 \\
\hline Manuscript Type: & Research Paper \\
\hline Keywords: & $\begin{array}{l}\text { conceptual change, misconception, science education, earth science } \\
\text { education }\end{array}$ \\
\hline Keywords (user): & \\
\hline
\end{tabular}

\section{s ScholarONE" \\ Manuscript Central}




\section{Primary Student-Teachers' Conceptual Understanding of the Greenhouse Effect: A Mixed Method Study}

The greenhouse effect is a reasonably complex scientific phenomenon which can be used as a model to examine students' conceptual understanding in science. Primary student-teachers' understanding of global environmental problems, such as climate change and ozone depletion, indicates that they have many misconceptions. The present mixed methods study examines Finnish primary student-teachers' understanding of the greenhouse effect based on the results obtained via open-ended and closed-form questionnaires. The open-ended questionnaire considers primary student-teachers' spontaneous ideas about the greenhouse effect depicted by concept maps. The present study also uses statistical analysis to reveal respondents' conceptualization of the greenhouse effect. The concept maps and statistical analysis reveal that the primary student-teachers' factual knowledge and their conceptual understanding of the greenhouse effect are incomplete and even misleading. In the light of the results of the present study, proposals for modifying the instruction of climate change in science, especially in geography, are presented.

\section{Introduction}

Climate change as a global environmental hazard has often been in the media. Climate change has huge social, environmental and economic consequences. Nowadays we are beginning to see some of the consequences of climate warming such as changes in weather patterns and the melting of the polar ice (IPCC, 2007). It seems evident that humans need to research and implement both global and local solutions in order to adapt to climate change. Globally, different nations have different interests to participate in the shared community 
effort on behalf of the climate: some nations participate under the pressure to create a better future, others escape their responsibility. How individual people understand and conceptualize complex climate warming plays a crucial role when they try to decrease their own impacts on climate. Locally, climate change has become an issue for discussion in the primary-, secondary- and upper secondary science classroom which affects the abilities of future decision-makers to solve the problems and to make appropriate and far-reaching decisions. Several European school curricula and policy document, including those of Finland, reveal the importance of developing students' decision-making skills based on science. It follows that the way future teachers receive their teacher education is not irrelevant.

A leading objective of Finnish education policy is to achieve as high a level of education and competence as possible for the whole population (FNBE, 2009). About 35\% of pupils continue on to upper secondary education when they leave comprehensive school. Finnish teachers are highly qualified and committed, and a Master's degree is a basic requirement. Teacher education also includes teaching practice. As the teaching profession enjoys high popularity in Finland, universities are in a position to select the most motivated and talented applicants.

At the University of Jyväskylä, the core of the science education programme for primary student-teachers comprises a student study of the teaching of a single science topic for the duration of one academic year. The majority of the teaching provided supports this project. The project includes content analysis, determining student ideas about the topic, finding, selecting or creating the most appropriate presentations and teaching strategies, and drawing up a practical teaching plan. The questionnaires used in the present study were conducted prior to the project. The present study nevertheless provided the impetus for 
several primary student-teachers to conduct their own studies of the teaching of climate change.

In Finnish schools the greenhouse effect is mainly taught in geography classes. Geography as a holistic science offers many opportunities also in education to participate in community climate efforts. According to previous studies (Nevanpää, 2005), traditional instruction has not achieved results that indicate pupils' understanding of climate change. There is still a need for more information about pupils' conceptual change during teaching.

The present study leans on systems thinking and concept mapping, which are widely used in science teaching. Bertalanffy (1972) recognized three aspects of the systems approach. Firstly, systems science deals with the scientific exploration of systems and systems theory in the various sciences. Secondly, systems technology deals with applications in both computer operations and theoretical developments such as game theory. Thirdly, systems philosophy addresses the reorientation of thought and world-view resulting from the introduction of systems as a new scientific paradigm. The present study draws on the latter, and systems thinking is conceived as the ability to recognize, describe and model complex aspects of reality as climatic systems. The important aspect of systems thinking is the ability to identify important elements of the climatic system and the varied interdependency between these elements. According to Ossimitz (2000), systems thinking incorporates four central dimensions: (1) network thinking, (2) dynamic thinking, (3) thinking in models, and (4) system-compatible action. Ben-Zvi Assaraf and Orion (2005) identified eight characteristic aspects of systems-level thinking: (1) identifying the components and processes of a system, (2) identifying processes that create relationships between system components, (3) constructing a framework of relationship, (4) drawing general conclusions, (5) understanding that a given relationship can impact other relationships, (6) knowing that there can be hidden 
dimensions that affect the system, (7) understanding the cyclical nature of systems, and (8) recognizing that systems can change over time.

In this study, concept mapping refers to the technique of schematically illustrating student knowledge of the elements of the greenhouse effect and the interdependencies between these elements in order to facilitate meaningful learning (Novak, 1990; Novak \& Cañas, 2008). The technique stems largely from Ausubel's Theory of Meaningful Learning (Ausubel, Novak, \& Hanesian 1978). According to this theory, concept mapping can also be the most important tool to systematize and describe the learners' prior knowledge. Concepts can consist of briefly presented forms of human experiment and the nodal points between the abstract and the concrete (Novak \& Cañas, 2008). In the present study the conceptualization of the greenhouse effect is divided in three major entities: figurative, model and molecular (see Lin \& $\mathrm{Hu}, 2003$ ), which were used to form a category framework for the understanding of the greenhouse effect.

The present study is focused on finding answers to the following questions:

- How do primary student-teachers conceptualize the greenhouse effect?

- What are their ideas about the consequences of and solutions to climate warming?

- How do their environmental attitudes, gender and scholastic achievement affect their conceptualization of the greenhouse effect?

A review of the research questions is presented at the end of study in order to develop the instruction of the greenhouse effect and climate warming in geography. 
Previous Research on the Conceptualization of the Greenhouse Effect

The present study examines primary student-teachers' understanding of the greenhouse effect. Despite the fact that climate change is daily presented in the media, people's factual knowledge and their conceptual understanding of climate warming and the greenhouse effect are incomplete and often misleading (Rickinsonin, 2001). Many people regard the greenhouse effect merely as an environmental problem and not necessary as the phenomenon that regulates the Earth's climate and keeps its temperature relatively stable, thus making life on the planet possible (Appendix 1). Scientifically, the mechanism of the greenhouse effect is caused by specific atmospheric gases, mainly water vapour $\left(\mathrm{H}_{2} \mathrm{O}\right)$, carbon dioxide $\left(\mathrm{CO}_{2}\right)$, methane $\left(\mathrm{CH}_{4}\right)$ low-level ozone $\left(\mathrm{O}_{3}\right)$ and nitrous oxide $\left(\mathrm{N}_{2} \mathrm{O}\right)$. The anthropogenic greenhouse effect, i.e. climate warming, means that Earth is now absorbing $0.85 \pm 0.15$ watts per square meter more energy from the Sun than it is emitting to space (simulation period 1880-2003) (Hansen et al., 2005). Climate warming is caused by elevated levels of greenhouse gases, which contribute to additional absorption and emission of long-wave radiation in the surfacetroposphere system.

Many researchers have found that student-teachers know the basic facts about climate warming, such as the increasing temperature of the Earth, but their knowledge is atomistic (Ratinen, 2008). It is not only students but also teachers who have misconceptions and misunderstandings about climate warming (Papadimitriou, 2004), and they probably pass their own ideas on to pupils.

Many studies (Table 1) show that it is common to confuse the greenhouse effect with the depletion of the ozone layer. Scientifically, the connection between climate warming and ozone depletion is not strong (IPCC, 2007). However, reduced ozone causes less solar radiation absorption in the stratosphere, thus cooling the stratosphere. As a result, the cooler 
stratosphere emits less long-wave radiation to the troposphere, thus in turn cooling the troposphere $\left(-0.15 \pm 0.10 \mathrm{~W} / \mathrm{m}^{2}\right)$. The problems of distinguishing between the greenhouse effect and ozone depletion may be due to problems in distinguishing IR radiation from UV radiation or even radiation from thermal energy (Boyes \& Stanisstreet, 1997). Moreover, primary school pupils think that the environment deteriorates, plants and animals are infected by pollution, and the air becomes dirty, which prevents heat from re-radiating and therefore the climate is hotter (Koulaidis \& Christidou, 1999). Jeffries, Stanisstreet, and Boyes (2001) found that more students held misconceptions in their later study than in the study which they made 10 years before. Groves and Pugh (2002) found that students held on to their misconceptions of the cause of climate warming even after instruction. According to Andersson and Wallin (2000), students cannot distinguish the greenhouse gases correctly and, for example, they believe CFCs are responsible for the climate warming because they destroy ozone, and create the ozone hole that allows UV rays to reach the earth.

With regard to environmental education it is interesting that many people link climate warming with the results of human action such as littering (Nevanpää, 2005). Indeed, studies of students' understanding of global environmental problem indicate that the students do not fully understand what fundamental societal changes (economy, business activities, infrastructure, social institutions, and the environment) would occur as a result of a drastic reduction in $\mathrm{CO}_{2}$ emission (Anderson \& Wallin, 2000).

Recently, students' views on global warming and their beliefs about actions to decrease global warming and their willingness to act have been an important research area (Boyes, Skamp, \& Stanisstreet, 2009). Their study indicates that altering beliefs about the usefulness of one's own action is not expected to produce noticeable changes in behaviour. Lester, Ma, and Lambert (2006) point out that pupils having a scientifically correct content knowledge of global warming tend to express activism toward global warming more frequently. Their 
finding that pupils gained better science knowledge after instruction showed the importance of education.

Based on earlier studies (see Table 1), seven scientific processes are developed and presented in this study. In the categorization of the responses of the present study's respondents, the identification of these key processes was used to discern different levels of understanding. The following concept categories were used:

\section{Model}

P1: Wave model. The Earth system receives energy from the Sun mainly in the form of visible light. Reflected short-wave radiation is distinguished from emitted long-wave radiation.

P2: Particle model. Photon energy is directly proportional to the wave frequency and a wave consists of discrete packets of energy called photons. The particle model describes how photons are emitted and absorbed by charged particles.

P3: Black body radiation. The Earth emits energy into space in the form of infrared radiation.

Molecular

P4: The atmosphere has different abilities to absorb radiation. The atmosphere absorbs infrared radiation by photons, which causes vibration and rotation of the greenhouse gas molecules. Thus radiation is converted into heat energy. The molecules of the greenhouse gases can vibrate because of their symmetry. These vibrations create a transient dipole moment. Therefore greenhouse gases can absorb and emit infrared radiation. 


\section{Figurative}

P5: Incoming and outgoing radiation may be influenced in different ways by the atmosphere.

P6: Different gases in the atmosphere have different abilities to absorb electromagnetic radiation at different wavelengths. Ozone in not a greenhouse gases in the stratosphere (UV-absorption) but it accelerates the greenhouse effect in the lower troposphere.

P7: The increasing concentration of gases in the atmosphere may be affected by positive radiative force.

Insert Table 1 about here.

\section{Mixed Methods and Procedures}

Three groups $(n=275)$ of second-year primary student-teachers at the University Jyväskylä, Finland, were asked to complete an open-ended and closed-form questionnaire. The student respondents had successfully completed their upper secondary school studies (Table 2) but had not studied science at university level prior to the questionnaire. The present study scrutinises how participants' scholastic achievements affect their conceptualization of the greenhouse effect.

The questionnaire was administered during initial science classes and no data was collected prior to the course. The greenhouse effect mechanism was taught subsequent to the questionnaire. Students completed the questions as individuals, but their anonymity was guaranteed. In the present mixed method study the qualitative questionnaire was collected before the quantitative questionnaire (QUAL->QUAN). The embedded design was used in 
which QUAN data set provides a supportive role in the study based on the QUAL data (see Creswell \& Plano Clark, 2005). Students' responses of the QUAL data sets were based on their writings and therefore their skills to write a coherent story about the greenhouse effect may be affected the results. However, embedded QUAN data sets were played a supplemental role for the more validate interpretation of the results.

The open-ended questionnaire (QUAL) helped to gain more insight into the respondents' thinking by obtaining their spontaneous responses without imposing answers, as occurs when using a closed-form questionnaire (QUAN). The latter type, however, enables us to scrutinise relationships between different students.

The open-ended questions asked were as follows: "What does the greenhouse effect mean?" and "What is the greenhouse effect caused by?" In the theory-based analysis of the open-ended questionnaire respondents' answers were first read and then classified into main categories and concept categories. Secondly, concepts maps based on the concept categories were drawn up. In addition, the frequencies of students' concepts were calculated.

The study by Jeffries, Stanisstreet, and Boyes (2001) was utilized to design the closedform questionnaire and nine questions were also added to probe students' environmental attitudes. Their study repeated the previous surveys' procedures, thus increasing the reliability and validity of the study. In addition, some questions used to investigate students' knowledge about the greenhouse effect were revised in the present study. The closed-form questionnaire also asked about the extent to which students thought they had learned about global warming from different sources (school, television, newspapers and magazines, radio, education). The background information collected by questionnaire included gender, date of birth, matriculation examination mark and the marks awarded for geography, biology, physics and chemistry in the upper secondary school diploma. The closed-form questionnaire took the form of statements to which the students were asked to respond by circling the 
appropriate word: "Right”, "Probably right", "Difficult to say", "Probably wrong” and Wrong". The items were arranged in three sections: real and possible consequences of an exacerbation of the greenhouse effect, real and possible causes, and real and possible cures. The first section contained eight, the second section six, and the third section five scientifically acceptable statements. In addition, the first and third sections contained five and the second section six scientifically unorthodox statements interspersed at random. The final page of the questionnaire asked students to record how much they thought they knew and how much they thought they had learned from different sources. In order to compare percentages, the two positive responses ("Right" and "Probably right") were combined to provide a measure of the proportion who agreed with an idea. Similarly, to indicate those who disagreed with an idea, the other two responses ("Probably wrong" and "Wrong") were combined.

Differences between the responses of male and female students, and between students' scholastic achievement were analysed using KW-ANOVA, as these factors can influence student conceptualization of the greenhouse effect (Jeffries, Stanisstreet, and Boyes 2001). Principal components analysis (PCA) was used to combine students' environmental attitudes and their responses to the questionnaire items about possible consequences, causes and cures of the greenhouse effect. Three principal components were extracted from the data on environmental attitudes and four from the students' opinions of the greenhouse effect. All principal components were varimax rotated and therefore independent. The principal components calculated from the attitude statements explained $48 \%$ of the total variance and $40 \%$ of the students' opinions of the greenhouse effect. The basic idea of PCA is to seek common variation among the many variables and from interpretative groups of variables.

Pearson's product moment correlation coefficient $(r)$ was used in the analysis of the impacts of environmental attitudes on the students' knowledge of the greenhouse effect. The 
Insert Table 2 about here.

\section{Mixed Analysis of Student Concepts of the Real and Possible Causes of the Greenhouse Effect}

The present study indicates that in their answers four \% of respondents wrote that the greenhouse effect is not the same as climate warming. According to these 12 primary studentteachers the Earth is a planet with life because the greenhouse effect keeps the temperature relatively stable and makes life on the earth possible. In their replies, the students suggested that the environmental problem results from the enhanced greenhouse effect, caused by emissions of man-made greenhouse gases. However, their answers to P2 and P7 were not very detailed even if the students had successfully passed their science classes (Table 2). In the closed-form questionnaire almost every student (99.6\%) agreed with the statement that if the greenhouse effect grows, the climate will change and the Earth will get hotter (94\%). This 
shows that primary student-teachers' conceptualization of the greenhouse effect is inadequate, but they are able to choose scientifically relevant statements in the questionnaire, thus underlining the importance of the use of a mixed method approach with respect to complex issues such as the greenhouse effect.

According to Papadimitriou (2004), many primary student-teachers confuse the greenhouse effect with climate change and 51\% view the greenhouse effect as being the cause of climate change. Nevanpää (2005) noted the same for students. In Swedish studies ten $\%$ of ninth grade students regarded the greenhouse effect as a natural phenomenon (Anderson \& Wallin, 2000). Among Finnish primary student-teachers, the conceptual confusion of these two phenomena is probably caused by the media, where climate change has been the concept discussed and not the greenhouse effect (Lyytimäki, 2007). Papadimitriou (2004) supposes that primary student-teachers have experience of short-term weather patterns from TV, which has supported their beliefs about climate change.

\section{Greenhouse Gases as a Source of the Greenhouse Effect}

Relatively few primary student-teachers (12\%) had conceptualized in their responses that the greenhouse effect and climate warming were caused by specific atmospheric gases such as carbon dioxide, methane and CFCs (Figure 1). The quantitative analysis indicated that many of the students (84\%) presumed CFCs to be greenhouse gases (Figure 2). The result is similar to that obtained by Jeffries, Stanisstreet, and Boyes (2001), but Papadimitriou (2004) points out that only $7 \%$ of primary student-teachers associated aerosols and sprays with the cause of climate change.

In the present study over $79 \%$ of primary student-teachers thought that (methane) gas from rotting waste contributed to climate change, but rather fewer $(37 \%)$ thought this true of 
Insert Figure 1 about here.

Insert Figure 2 about here.

According to five primary student-teachers (2\%), the greenhouse effect and climate warming is caused by the thinning atmosphere, which means that these students have not conceptualized the greenhouse effect in a scientifically precise manner (P1-P7), (Figure 3). Generally, students expressed the view that pollutants, emissions, industry and natural devastation thin the atmosphere. Based on earlier studies, the students may logically think that the decreasing of the "protective layer" of the atmosphere makes the atmosphere hotter (see Christidou \& Koulaidis, 1996; Nevanpää, 2005). Koulaidis and Christidou point out (1999) that primary school pupils thought that living things are infected by air pollution, and that this pollution destroys the atmosphere and makes the climate hotter. The primary student-teachers involved in the present study inquiry have likely misunderstood the atmosphere as being a homogenised structure where the ozone layer is an essential and lifeprotecting atmospheric component because it absorbs incoming UV radiation. 
Insert Figure 3 about here.

\section{Disturbed Radiative Forcing is the Reason for the Greenhouse Effect}

Relatively few primary student-teachers $(10 \%)$ wrote that disturbed radiative forcing causes the greenhouse effect and climate warming (Figure 4). In the closed-form questionnaire of the present study, however, considerably more students (60\%) associated the statement about the entrapment of the Sun's rays with climate warming (Figure 2). In the study of Jeffries, Stanisstreet, and Boyes (2001) more than $80 \%$ of students stated that global warming occurs because the Sun's rays cannot escape.

Because the result analysed on the basis of qualitative and quantitative questionnaires clearly differs, it is useful to examine students' responses further. Students who belong to this concept category emphasized that the Sun's rays cannot escape, but they did not make clear in their responses the conceptual distinction between sunlight and terrestrial radiation. Therefore respondents did not understand the mechanism of black body radiation (P3) and the enhanced greenhouse effect caused by greenhouse gases (P4). Figure 4 indicates clearly the way pollutants and emissions constitute a layer which prevents radiation from reflecting out into the atmosphere. This kind of misconception is fairly common among students (Koulaidis \& Christidou, 1999; Papadimitriou, 2004). In fact, atmospheric aerosols increase albedo (see Kuusisto \& Käyhkö, 2004). Similarly, rather few students associated the ozone layer with the decreasing of terrestrial radiation (compare Figure 8). Although many students correctly identified the mechanism of climate warming, many (53\%) also chose the wrong mechanism, when more of the Sun's rays penetrate the Earth system (Figure 2). 
Insert Figure 4 about here.

\section{The Greenhouse Effect is the Result of Simple Causality}

Compared to earlier studies (Andersson \& Wallin, 2000; Nevanpää, 2005), rather few (9\%) primary student-teachers in the present study simplified the greenhouse effect to merely the causes and consequences of climate warming (Figure 5). Nevertheless, quite many students associated acid rain (44\%) and radioactive waste (30\%) with the greenhouse effect (Figure 2). Students in this category, for example, associated pollutants, emissions and deforestation with global warming but they did not understand climate warming as a broad scientific process. Myers, Boyes, and Stanisstreet (1999) found that school students' statements, giving pollution as the cause of the greenhouse effect or global warming, are more common amongst older students. Myers, Boyes and Stanisstreet (1999) suggest that the older the students are, the more aware they are of global, but very abstract, phenomena. It is possible that the respondents in the present study have studied climate warming at school, and also from secondary sources such as the media, but their understanding has not attained the level of model or molecular. It is also possible that climate warming is largely a matter of belief (Papadimitriou, 2004). All in all, climate warming is a complex issue with many negative and positive feedback mechanisms, which makes it challenging to learn.

Insert Figure 5 about here. 


\section{The Greenhouse Effect is Depicted by Non-scientific Statements}

Primary student-teachers' responses revealed that rather few of them (4\%) associated illogical issues with the greenhouse effect and climate warming (Figure 6). Papadimitriou (2004) found that very few (7\%) primary student-teachers spontaneously associate waste disposal or radioactive waste with the greenhouse effect. The quantitative questionnaire of the present study also indicates that students did not make an erroneous connection on the one hand between street littering (79\%) and rubbish in rivers (65\%), (Figure 2) and on the other hand climate change (99.6\%) and global warming (94), (Table 3). Instead, the students causally associated radioactive waste (30\%) and acid rain (44\%) with climate warming. According to Jeffries, Stanisstreet, and Boyes (2001), students may suppose both radioactive waste and acid rain to be "gaseous" forms of pollution, which may play a role in the generation of these misunderstood associations.

This category was called illogical because students' responses did not indicate the mechanism by which, for example, ice ages and the Earth's magnetospheric changes affect climate warming. Thus, the respondents' choice of expression did not demonstrate the analytical and scientific power of deduction.

Anderson and Wallinin (2000) point out that ten \% of students in the upper secondary school responded only by describing the results and causes of the greenhouse effect. Nevanpää (2005) found that the secondary school pupils were aware of the causes and results of the greenhouse effect both before and after instruction.

Insert Figure 6 about here. 


\section{A Greenhouse as an Analogy of the Greenhouse Effect}

Climate warming has been illustrated in the media and at schools by the actual greenhouse. However, according to the present study, the analogy depicts the greenhouse effect scientifically vaguely (Figure 7). Relatively few primary student-teachers (10\%) wrote that pollutants, emissions and greenhouse gases constitute a layer in the atmosphere which causes climate warming. Respondents thought that the "layer" acts like a glass pane in an actual greenhouse which physically prevents heat from radiating out into space. Similarly, they associated the statement that the Sun's rays cannot escape (60\%) with the greenhouse effect. Atmospheric greenhouse gases trap heat within the Earth's surface and troposphere system heating up the earth (P4). However, the students did not spontaneously depict the chemical reactions of the greenhouse gases in their responses. In an actual greenhouse the mechanism is fundamentally different because there air is isolated by the glass so that is not lost by convection and conduction.

Insert Figure 7 about here.

The Conceptual Distinction between the Roles of the Ozone Layer and the Greenhouse Effect

According to the quantitative analysis of the present study, many primary student-teachers (84\%) correctly stated that CFCs are greenhouse gases. Probably students know that CFCs are the major agent for ozone layer degradation, which confuses their thinking about the phenomena of ozone layer depletion and climate warming (Boyes \& Stanisstreet, 1993; Jeffries, Stanisstreet, \& Boyes, 2001). In the present study comparatively few (34\%) students associated ground level ozone with climate warming. Naturally, it may be difficult for 
students to be aware that ozone layer depletion is harmful to the environment and that therefore ozone is needed in the stratosphere but ozone is also the greenhouse gas at lower level of the troposphere. The process of ozone depletion in the stratosphere occurs because ozone is decreased through photo-chemical reactions caused by certain man-made substances, CFCs, halons and nitrogen oxides. This depletion is responsible for the ozone hole that allows more UV radiation to reach the Earth and threaten plant and animal life. A number of earlier studies from different countries have indicated that people causally connect ozone layer depletion with the greenhouse effect (Rye, Rubba, \& Wiesenmayer, 1997, in Pennsylvania from grade 6 to 8; Jeffries, Stanisstreet, \& Boyes, 2001, in UK for year 1 biology students; Papaditmiou, 2004, in Greece for primary student-teachers; Nevanpää, 2005, in Finland from grade 7 to 9). According to Papadimitriou (2004), primary studentteachers have given the explanation that the ozone hole allows more sunlight to penetrate the atmosphere, which heats the Earth. Similarly, primary student-teachers of the present study $(49 \%)$ indicated the conceptual distinction between the roles of ozone layer depletion and climate warming (Figure 8). A comparatively high proportion of students (74\%) endorsed the statement that the greenhouse effect is worsened by holes in the ozone layer. According to Boyes and Stanisstreet (1997) and Nevanpää (2005), but not noted in the present study, students have also thought that climate warming is one reason for ozone layer depletion. Scientifically, ozone layer depletion is considered an important factor in global climate change, due to its potential to affect the radiative balance of atmosphere and the formation of polar stratospheric clouds. When the ozone layer depletion accelerates, the stratosphere cools off, because the smaller the amount of ozone, the less energy released from UV absorption. A runaway greenhouse effect also makes the stratosphere cooler and therefore in the stratosphere there are more polar stratospheric clouds, which accelerate the depletion of 
ozone molecules. For this reason it is not unexpected that students may conceptually confuse climate warming and ozone layer depletion.

Some primary student-teachers $(20 \%)$ associated ozone layer depletion with increasing radiation or UV radiation (Figure 8). The latter is true for the Earth's surface, but students did not understand that the Earth receives energy from the Sun mostly in the form of visible light (P1). Students appreciated that the ozone hole in the atmosphere is the result of pollution, etc., when the Sun's rays (heat) pass through the ozone layer without being filtered by it. Moreover, many students simply thought, without any explanation, that the greenhouse effect is the result of ozone layer depletion. According to the present study, students did not confuse the scientific concepts but their understanding was based on everyday thinking. The mechanisms for how ozone layer depletion causes climate warming described by students are not generally based on scientific thinking. Rye, Rubba, and Wiesenmayer (1997) found that students often think that the heat from the increased sunlight warms up the planet.

According to the present study and the study of Koulaidis (1999) and Nevanpää (2005), students associated different pollutants and emissions with ozone layer depletion. Moreover, different chemicals (Figure 8, $\mathrm{n}=40$ ), as seen in earlier studies (Rye, Rubba, \& Wiesenmayer, 1997), were one of mechanisms which deplete the ozone layer. The respondents' thoughts about human activity such as deforestation, industry and traffic, along with Fisher's (1998) study, indicate that students associated people with the reason for ozone layer depletion.

Insert Figure 8 about here. 


\section{Students' Ideas about Real Possible Consequences of the Greenhouse Effect}

According to the present study, respondents (94\%) thought that the Earth would get hotter if the greenhouse effect were to increase (Table 3). Almost all of the students were aware that the greenhouse effect and climate warming could increase melting of polar ice (94\%), change weather patterns $(99.6 \%)$ and cause more flooding (94\%). More than half argued that there would be more desert (77\%) and insect pests (64\%) on the Earth due to climate warming. Percentages are similar to the results of Jeffries, Stanisstreet, and Boyes (2001).

It seems obvious that the respondents in the present study have a rather good understanding of the real consequences of the enhanced greenhouse effect because relatively few students associated food poisoning (12\%), heart attacks (16\%) or earthquakes (25\%) with the effect of climate warming. Nevertheless, the most common misconception, held by $79 \%$ of students, was that an increase in the greenhouse effect would result in a rise in the occurrence of skin cancer. The results are similar to other studies (e.g. Jeffries, Stanisstreet, \& Boyes, 2001). It is clear, therefore, that students have confused the greenhouse effect with ozone layer damage.

Insert Table 3 about here.

\section{Students' Ideas about Real Possible Cures of the Greenhouse Effect}

The quantitative data for answers to statements about human actions which possibly reduce the greenhouse effect were examined in the present study (Figure 9). Most of the primary student-teachers appreciated the need for reduced use of vehicles (97\%), using more wind power $(90 \%)$ and the implementation of tree planting programmes $(83 \%)$ to minimize climate 


\title{
Students' Self-perceived Knowledge and Sources of Information about the Greenhouse Effect.
}

\begin{abstract}
About two-thirds of the primary student-teachers thought that they knew a lot or something about the greenhouse effect. More males thought themselves to hold correct beliefs about the greenhouse effect $\left(\chi^{2}(1)=21.196, \mathrm{p}<.001, d=.686\right)$. Students' scholastic achievement did not affect their self-perceived knowledge. According to the present study, students' selfperceived knowledge and their understanding of the greenhouse effect do not correspond because only $4 \%$ of respondents conceptualized the greenhouse effect in a scientifically correct way in the open-ended questionnaire. A high proportion of respondents stated that they had learnt about the greenhouse effect in school (67\%), from the media (TV and radio, $61 \%$ ) or during university studies (47\%), (Table 4$)$.
\end{abstract}

Insert Table 4 about here. 


\section{Differences in Responses by Gender, by Science Studies and by Matriculation}

\section{Examination results}

The present study indicates that there were differences between male and female responses along 12 variables. More of the males realised that if the greenhouse effect worsens, desertification will accelerate $\left(\chi^{2}(1)=3.947, \mathrm{p}<.047, d=.327\right)$ and sea level will rise $\left(\chi^{2}(1)\right.$ $=8.297, \mathrm{p}<.004, d=.439)$. They also associated more with the idea of the Sun's rays being trapped as a real mechanism of an enhanced greenhouse effect $\left(\chi^{2}(1)=5.136, \mathrm{p}<.023, d=\right.$ .304). Females had more misconceptions, thinking that trash on the streets $\left(\chi^{2}(1)=6.820, p<\right.$ $.009, d=.374)$, radioactive waste $\left(\chi^{2}(1)=19.371, \mathrm{p}<.001, d=, 717\right)$, acid rain $\left(\chi^{2}(1)=\right.$ $12.979, \mathrm{p}<.001, d=.552)$ and earthquakes $\left(\chi^{2}(1)=5.216, \mathrm{p}<.022, d=.346\right)$ contributed to the greenhouse effect. At the same time, females more often expressed the idea that ground level $\mathrm{O}_{3}$ accelerates the greenhouse effect $\left(\chi^{2}(1)=11.011, \mathrm{p}<.001, d=.507\right)$. The questionnaire asked for respondents' opinions on actions for decreasing the greenhouse effect. Females more often wrongly conceptualised that eating healthy food $\left(\chi^{2}(1)=4.447\right.$, p $<.035, d=.247)$, avoiding use of nuclear bombs $\left(\chi^{2}(1)=17.279, \mathrm{p}<.001, d=.570\right)$ and protecting rare species $\left(\chi^{2}(1)=4.991, \mathrm{p}<.025, d=.333\right)$ would diminish the greenhouse effect. In contrast, males correctly saw nuclear power $\left(\chi^{2}(1)=23.402, \mathrm{p}<.001, d=.702\right)$ and recycled paper $\left(\chi^{2}(1)=5.241, \mathrm{p}<.022, d=.246\right)$ as actions which will reduce the greenhouse effect.

According to the results of the KW-ANOVA in the present study, the level of respondents' success in upper secondary school studies did not very significantly affect their views regarding the greenhouse effect. However, the better the matriculation examination performance, the more likely students were to consider reduced poisoning of fish and water systems as a result of the greenhouse effect $\left(\chi^{2}(4)=9.825, \mathrm{p}<.043\right)$. Similarly, high-scoring 
students thought that radioactive waste does not contribute to the greenhouse effect $\left(\chi^{2}(4)=\right.$ $10.008, \mathrm{p}<.040)$ and that the phenomenon cannot be mitigated by keeping beaches clean $\left(\chi^{2}(4)=9.660, p<.047\right)$. Respondents who had successfully completed upper secondary school studies therefore held slightly fewer misconceptions about the causes of the greenhouse effect.

In Finnish schools the greenhouse effect is mainly taught in geography classes. Students who scored well (mark 8.7) in their geography courses at upper secondary school were more prone to see more flooding as a consequence of the greenhouse effect $\left(\chi^{2}(4)=\right.$ $10.132, \mathrm{p}<.038)$. Simultaneously, they less frequently thought that nuclear power will decrease the greenhouse effect $\left(\chi^{2}(4)=9.641, \mathrm{p}<.047\right)$. Similarly, students with excellent marks (9-10) thought that poisoned fish in water systems is not a consequence of the greenhouse effect $\left(\chi^{2}(4)=10.566, p<.038\right)$, but the increasing $\mathrm{CO}_{2}$ level in the atmosphere $\left(\chi^{2}(4)=12.212, p<.016\right)$ and the fact that the Sun's rays cannot escape from the atmosphere will worsen the greenhouse effect $\left(\chi^{2}(4)=12.375, p<.015\right)$.

\section{Students' Environmental Attitudes and Their Thinking about the Greenhouse Effect}

Environmental attitudes were investigated in terms of environmental attitude variables employing statements designed to relate to attitudes towards nature, science, technology and economic growth. Consequently the question is different from those used by Ratinen (2005), for example. There were both optimistic and pessimistic statements of attitudes, the optimistic variables expressing high hopes for a future in which attitudes will be affected by people's own activity while the pessimistic variables illustrated the fact that people at present are passive in their environmental actions and do not think that the environmental problems are serious. 
Students in general adopted a positive view towards environmental attitudes. Only about $2 \%$ said: "I do not care about the destruction of nature," and most of them (93\%) maintained that a built landscape was not as beautiful as a natural landscape and nature would have to be protected even if it does not increase welfare (86\%). Ratinen (2005) found similar results, with $87 \%$ of his respondents totally or moderately agreeing that nature conservation is important. A parallel result of his showed that $95 \%$ of people thought that it was important to protect the environment even if not everybody wished to do so. $84 \%$ of students totally or moderately agreed that people have to change their lifestyle completely in order to save nature. The results were similar to those reported by Tulokas (2002), Ratinen (2005), (see Özden, 2008). In the present study $59 \%$ of students were ready to compromise on their own welfare for the better future of the environment. When the claim was made that ordinary people cannot do anything about the state of the environment, $96 \%$ of the respondents partially or totally disagreed with this, suggesting that they understand their own ability to influence the state of the environment. Improving the environment was a complex process and for this reason $16 \%$ of the students believed that they could not achieve it to an appreciable extent. At the same time, students did not in general believe in technology and science, as $51 \%$ of the respondents were of the view that these could not solve environmental problems. The percentage reported by Ratinen (2005) was similar. Finally, students (96\%) thought that attention must be paid to the state of the environment.

Males more often adopted a pessimistic view towards environmental attitudes. They thought that it was not important to protect the environment even if not everybody wished to do so $\left(\chi^{2}(1)=7.769, \mathrm{p}<.005, d=.367\right)$ and males did not believe in their opportunities to prevent the deterioration of the environment $\left(\chi^{2}(1)=8.127, \mathrm{p}<.004, d=.415\right)$. However, males more often expressed the view that science and technology can solve environmental problems $\left(\chi^{2}(1)=8.748, \mathrm{p}<.003, d=.448\right)$. 
Three principal components were calculated by PCA (Table 5). Variables

demonstrating that students did not care about the state of nature was loaded $(>.5)$ on the first component, called Pessimism, while the second component, called Protection, indicated students' attitudes towards environmental protection. Variables which indicated students' attitudes towards nature, science, technology and the anthropogenic environment were given the name Techno. These principal components together explained $48 \%$ of the total variance.

Insert Table 5 about here.

In order to identify themes running through students' thinking about the consequences and cures of the greenhouse effect, the data were analyzed by PCA. All principal components were orthogonal and therefore independent. All of the statements in principal component 1 , called Awareness, with $>.5$ loadings related to correct ideas about cures of the greenhouse effect (Table 6). Thus students thought that wind energy, planting trees, recycling paper, conserving energy, reducing car use and nuclear power were all ways to lessen the greenhouse effect. Maybe trees have to be seen as absorbing $\mathrm{CO}_{2}$ from the atmosphere and recycled paper as saving trees, as Jeffries, Stanisstreet, and Boyes, (2001) found.

The second component, named Misconceptions, indicated erroneous ideas about cures of the greenhouse effect. Namely, keeping beaches clean, reducing the nuclear arsenal and protecting rare species would help to reduce the greenhouse effect. These misconceptions are present also in young school students (Boyes \& Stanisstreet, 1993), in undergraduate students (Jeffries et al. 2001) and in the context of the Finnish lower secondary school (Nevanpää, 2005). 
Three consequences were loaded in principal component 3, called Consequences, in which students indicated that melting polar ice, rising sea level and changing climate are possible consequences of the increasing greenhouse effect.

The last component is depicted by food poisoning, fish being poisoned in water systems and people getting heart attacks, named Illness. The fact that students' beliefs about the greenhouse effect may result in erroneous ideas about the consequences of the greenhouse effect suggests that there may be some uncertainly in students' understanding of this issue. These principal components together explained $40 \%$ on the total variance.

Insert Table 6 about here.

\section{Discussion and Implications}

How do primary student-teachers conceptualize the greenhouse effect?

These mixed methods results demonstrate that primary student-teachers' knowledge about the greenhouse effect and climatic change are insecure. For example, the conceptualization of the greenhouse effect as a natural phenomenon that regulates the Earth's climate is not clear.

From the systems thinking point of view, their conceptualization of the greenhouse effect is more at the figurative level than the model or molecular level. Relatively few students understand correctly the nature of solar radiation and its mechanism in the greenhouse effect. The results indicate that students have insufficiently conceptualized the wave and particle model and, in particular, the transient dipole moment of greenhouse gases. In the other words, students did not have a good understanding of the mechanism of the greenhouse effect caused by greenhouse gases, water vapour, carbon dioxide, methane, low-level ozone and nitrous 
oxide. The open-ended questionnaire indicates that students' understanding of atmospheric processes is incomplete because some of them also associated pollution with the greenhouse effect. The closed-form questionnaire revealed the students' understanding of atmospheric gases from a different point of view. Namely, fewer than half of the students knew that ground level ozone acts as a greenhouse gas. All in all, there were no mentions of ground level ozone in the students' replies to the open-ended questionnaire. Eight-tenths of the students imagined that there was a link between the greenhouse effect and skin cancer, and they had an incorrect model of climate warming, which involved excess penetration of solar radiation at the Earth, maybe via holes in the ozone layer. Students incorrectly relate the greenhouse effect to ozone layer depletion and their misconceptions are related to lack of scientific knowledge. Qualitative analyse indicated that IR radiation was not usually mentioned in connection to the greenhouse effect. Instead, according to the quantitative analysis, UV radiation was confused to thermal radiation. The present study reveals that primary student-teachers' knowledge of the greenhouse effect was inadequate. There is a strong possibility that students have not achieved the three first levels of systems thinking (identifying the components and processes of a system, identifying processes that create relationships between system components, and building up a framework of relationship) in their studies in upper secondary school. Therefore, the basis for a holistic understanding of the greenhouse effect is lacking.

What are students' ideas about the consequences of and solutions to climate warming?

Primary student-teachers have a rather good understanding of the real consequences of the enhanced greenhouse effect. They especially thought that climate warming could change weather pattern. Some misconceptions were common. Almost half of the students thought of 
acid rain as a consequence of climate warming and more than half of them thought that unleaded petrol would reduce the greenhouse effect.

\author{
How do students' environmental attitudes, gender and scholastic achievement affect their \\ conceptualization of the greenhouse effect?
}

Students have, in general, positive and environmentally friendly attitudes towards the environment. Notable is that $59 \%$ of students were ready to compromise on their own welfare for the better future of the environment and they believe (51.3\%) that science and technology could solve environmental problems. The PCA indicated that the less the present students knew of the consequences and cures of climate warming, the more they held environmentally friendly attitudes. The result is noteworthy and this has to be taken into account in science education.

Females had more misconceptions and they more often thought that non-scientific consequences such as radioactive waste and acid rain would accelerate the greenhouse effect. Similarly, females more often wrongly conceptualized that eating healthy food, avoiding use of nuclear bombs and protecting rare species would diminish the greenhouse effect.

The present study indicates that students' success in their studies at upper secondary school did not very significantly affect their opinion on the greenhouse effect. However, the high-scoring of the matriculation examination certificate marks decreased students' misconceptions about the cause of greenhouse effect such as acid rain and holes in the ozone layer exacerbate the greenhouse effect. 
Implications for instruction

Understanding science is difficult for primary student-teachers because abstract processes are involved, such as the electromagnetic spectrum, wavelength, absorption and re-emission of electromagnetic energy. Especially, the molecular level is difficult to achieve. Therefore, in the science class emphasis should be placed on the chemical reactions of the greenhouse gases, and a closer look taken at how IR rays are absorbed into the atmospheric gases.

Moreover, it has to be kept in mind that CFCs - but not carbon dioxide - have two undesirable effects on the atmosphere. Further, the different layers in the atmosphere and their different physico-chemical reactions should be carefully taught in the science class. All in all, it seems obvious that the illustrative level of instruction is not sufficient for teaching the greenhouse effect in teacher education.

It is possible that traditional ways of teaching, which are based on transmission of knowledge, are inappropriate because they do not help students to use the knowledge learned in order to understand real issues from everyday life. As Papadimitriou (2004) points out, demonstrations or local surveys are also inappropriate due to the abstract nature of science. Therefore innovative pedagogical strategies are needed, such as concept mapping and the modelling approach, in order to teach complex environmental issues such as climate warming. Concept mapping would be beneficial in initial teacher education because it helps learners to restructure their knowledge of climate warming. Concept mapping, which include positive measures to avoid increasing the greenhouse effect can help not only understand the climate warming but can contribute to form conscious citizens.

Science teaching then explores and organises learners' ideas in order to align them with scientific views of climate warming. Pupils and students may also assimilate new ideas and experiences of their beliefs regarding measures to decrease global warming and their 
willingness to act to avoid increasing the greenhouse effect, as Boyes, Skamp, and Stanisstreet (2009) point out. However, it should be borne in the mind that it would be beneficial to base learning and teaching on socio-constructivism where students spontaneously collaborate.

In university education it would be good to replace the actual greenhouse as an analogy for climate warming with a systems approach (see Ben-Zvi Assaraf \& Orion, 2005) with physico-chemical reactions, because it does not function using the same mechanism as the atmosphere. Greenhouses work primarily by preventing convection, whereas the atmospheric greenhouse effect reduces radiation loss, not convection. Comprehensive understanding of the greenhouse effect provides that students understand how greenhouse gases molecules absorb long-wave radiation.

In the class geography it would be possible to teach the greenhouse effect as a complex scientific phenomenon which calls for an interdisciplinary approach in order to understand the scientific thinking of students. Moreover, it would be necessary to take into account the different localization and distribution of greenhouse gases and the ozone layer in the atmosphere during geography classes. The fact is that greenhouse gases are spread in the troposphere, whereas ozone is localized in a relatively thin layer in the atmosphere. Despite the fact that the atmosphere is stratified, secondary school students (Nevanpää, 2005) have suggested that carbon dioxide may absorb UV radiation and thus destroy the ozone layer.

Key environmental issues must be included in the teacher education curriculum. These students will one day be teachers of young pupils in school, helping them in turn to understand the debate in society related to climate warming and to make decisions based on science. In the light of the present study, however, primary student-teachers do not have adequate knowledge to teach the abstract concepts of the greenhouse effect. Climate change is a challenge to environmental educators and researchers because it is an issue that is 


\title{
Notes for Future Research
}

\begin{abstract}
A possible subsequent area of research would be the study of possible solutions for the mitigation of climate warming (Appendix 1). For example, reforestation and keeping up of earth's surface vegetated decrease surface spectral emission. When vegetation standing and it is articulated with regional and global warming, people probably understand their proposal of paying for the avoided deforestation or paying for native forest restoration. In the future, educational research should be focused on teaching and learning sequences for gaining a better understanding of the mechanism of the greenhouse effect. Moreover, research in
\end{abstract}


science and social science should consider concrete measures to avoid the acceleration of the greenhouse effect. Human activities have increased the carbon dioxide concentration of the atmosphere. The best way to protect the climate is thus to reduce the level of atmospheric carbon dioxide. Comprehension of the greenhouse effect may encourage the public to take actions, such changing personal lifestyles, which would otherwise be unpopular.

Unfortunately, education alone cannot solve climate crises. The economic, political and social dimension of the greenhouse effect and geoengineering (at university level) should therefore be considered in instruction. Without adequate scientific knowledge, people may non-critically view geoengineering - such as iron fertilization of oceans to extract $\mathrm{CO}_{2}$ from the atmosphere (Bertram, 2010) - as providing a ready solution to the problem of climate warming, remaining unaware of the considerable possible side-effects inherent to such solutions, such as ocean acidification (Caldeira \& Wickett, 2003; Wayman, (2008). Climatic warming is, clearly, an important educational concern.

\section{References}

Andersson, B \& Wallin, A. (2000). Students' understanding of the greenhouse effect, societal consequences of reducing $\mathrm{CO}_{2}$ emissions and why ozone layer depletion is a problem. Journal of Research in Science Teaching, 37(10), 1096-1111.

Ausubel, D.P., Novak, J.D. \& Hanesian, H. (1978). Educational Psychology: A Cognitive View. New York: Holt, Rinehart \& Winston.

Ben-Zvi Assaraf, O. \& Orion, N. (2005). Development of system thinking skills in the context of earth system education. Journal of Research in Science Teaching, 42(5), $518-560$.

Bertalanffy, von L. (1972). General System Theory. New York: Braziller. 
Bertram, C. (2010). Ocean iron fertilization in the context of the Kyoto protocol and the postKyoto process. Energy Policy, 38(2), 1130-1139.

Boyes, E. \& Stanisstreet, M. (1993). The “greenhouse effect": children's perceptions of causes, consequences and cures. International Journal of Science Education, 15(5), $531-552$.

Boyes, E. \& Stanisstreet, M. (1997). Children's models of understanding of two major global environmental issues (ozone layer and greenhouse effect). Research in Science \& Technology Education, 15(1), 19-28.

Boyes, E., Skamp, K. \& Stanisstreet, M. (2009). Australian secondary students’ views about global warming: Beliefs about actions, and willingness to Act. Research Science Education, 39(5), 661-680.

Caldeira, K. \& Wickett, M.E. (2003). Anthropogenic carbon and ocean $p$ H. Nature 425, 365365.

Christidou, V. \& Koulaidis, V. (1996). Children's models of the ozone layer and ozone depletion. Research in Science Education, 26(4), 421-436.

Cohen, J. (1988). Statistical power analysis for the behavioral sciences, 2nd ed. Hillsdale, NJ: Lawrence Erlbaum.

Creswell, J.W. \& Plano Clark, V.L. (2005). Designing and Conducting Mixed Methods Research. London: Sage Publications.

Ekborg, M. \& Areskoug, M. (2006). How students teachers' understanding of the greenhouse effect develops during a teacher education programme. Nordina 2 5(3), 17-29.

FNBE. Overview of the Educational System. Retrieved July 14, 2009, from http://www.oph.fi/english/education/overview_of_the_education_system

Fisher, B. (1998). Australian students' appreciation of the greenhouse effect and the ozone hole. Australian Science Teacher Journal, 44(3), 46-55. 
Gowda, R., Fox, J. \& Magelky, R. (1997). Students' understanding of climate change: Insights for scientist and educators. Bulleting of the American Meteorological Society, $78(10), 2232-2240$.

Groves, F. \& Pugh, A. (2002). Cognitive illusions to learning as hindrances to complex environmental issues. Journal of Science Education and Technology, 11(4), 381-390.

Hansen, J., Nazarenko L., Ruedy, R., Sato, M., Willis, J., Del Genio, A., Koch, D., Lacis, A., Lo, K., Menon, S., Novakov, T., Perlwitz, J., Russell, G., Schmidt, G.A. \& Tausnev, N. (2005). "Earth's Energy Imbalance: Confirmation and Implications". Science 308(5727), $1431-1435$.

IPCC. (2007). The physical science basis. Contribution of working group I to the fourth assessment report of the intergovernmental panel on climate change. Cambridge: Cambridge University Press.

Jeffries, H., Stanisstreet, M. \& Boyes, E. (2001). Knowledge about the "Greenhouse effect": have college students improved. Research in Science \& Technological Education, 19(2), 205-221.

Komorek, M. \& Duit, R. (2004). The teaching experiment as a powerful method to develop and evaluate teaching and learning sequences in the domain of non-linear systems. International Journal of Science Education 26(5), 619-633.

Koulaidis, V. \& Christidou, V. (1999). Models of students' thinking concerning the greenhouse effect and teaching implications. Science Education, 83(5), 559-576.

Kuusisto, E. \& J. Käyhkö (2004). Globaalimuutos: Suomen Akatemien Figareohjelma. [Global change: the Figare programme of the Finnish Academy] Helsinki: Otava. 
Lester, B.T., Ma, L., Lee, O. \& Lambert, J. (2006). Social Activism in Elementary Science Education: A science, technology, and society approach to teach global warming. International Journal of Science Education, 28(4), 315-339.

Lin, C-U. \& Hu, R. (2003). Student's understanding of energy flow and matter cycling in the context of the food chain, photosynthesis and respiration. International Journal of Science Education, 25(12), 1529-1544.

Lyytimäki, J. (2007). Katastrofin aineksia? Ilmastokysymysten uutisointi ja lukutaito. [Recipe for catastrophe? News broadcasts and literacy related to climate questions] Lecture presented during Finnish Environmental Education conference, 11.10.2007. Myers, G., Boyes E. \& Stanisstreet, M. (1999). Something in the air: school students' ideas about air pollution. International Research in Geographical and Environmental Education, 8(2), 108-119.

Nevanpää, T. (2005). "Sillä vois olla jotain tekemistä näitten kasvihuonekaasujen kanssa" Ilmastonlämpeneminen yläluokkalaisten käsityksissä. ["It might have something to do with these greenhouse gases" 7-9th graders' conceptions of climate warming] University of Jyväskylä. Institute for Educational Research. Research Reports 17.

Novak, J.D. (1990). Concept maps and vee diagrams: Two metacognitive tools to facilitate meaningful learning. Instructional Science, 19, 29-52.

Novak, J.D. \& Cañas, A.J. (2008). The Theory Underlying Concept Maps and How to Construct and Use Them. Retrieved July 14, 2009, from http://cmap.ihmc.us/Publications/ResearchPapers/TheoryCmaps/TheoryUnderlyingCon ceptMaps.htm

Ossimitz, G. (2000). Entwicklung systemischen Denkens. Theoretische Konzepte und empirische Untersuchungen [Development of systems thinking: Theoretical concepts and empirical studies]. München: Profil-Verlag. 
Papadimitriou, V. (2004). Prospective primary teachers' understanding of climate change, greenhouse effect, and ozone layer depletion. Journal of Science Education \& Technology, 13(2), 299-307.

Ratinen, I. (2005). Fish farming as a local geographical system. The case of Kustavi, Finland. University of Joensuu, Department of Geography. Publications 11.

Ratinen, I. (2008). Luokanopettajaksi opettajaksi opiskelevien käsitykset kasvihuoneilmiöstä ja ilmiön opettaminen maantieteessä. [Teacher education students' conceptions of the greenhouse effect and its teaching in geography]. Terra, 120(4), 235-242.

Rickinson, M. (2001). Learners and learning on environmental education: a critical review of the evidence. Environmental Education Research, 7(3), 207-316.

Rye, J., Rubba, P.A. \& Wiesenmayer, R.L. (1997). An investigation of middle school students' alternative conceptions of global warming. International Journal of Science Education, 19(5), 527-551.

Tulokas, R. (2002). Suomalaiset ja ympäristö. [Finns and the environment] Helsinki: Statistics Finland.

Wayman, E. (2008). Seeding the sea. Geotimes 53(8):40-47.

Özden, M. (2008). Environmental awareness and attitudes of student teachers: An empirical research. International Research in Geographical and Environmental Education, $17(1), 40-55$. 


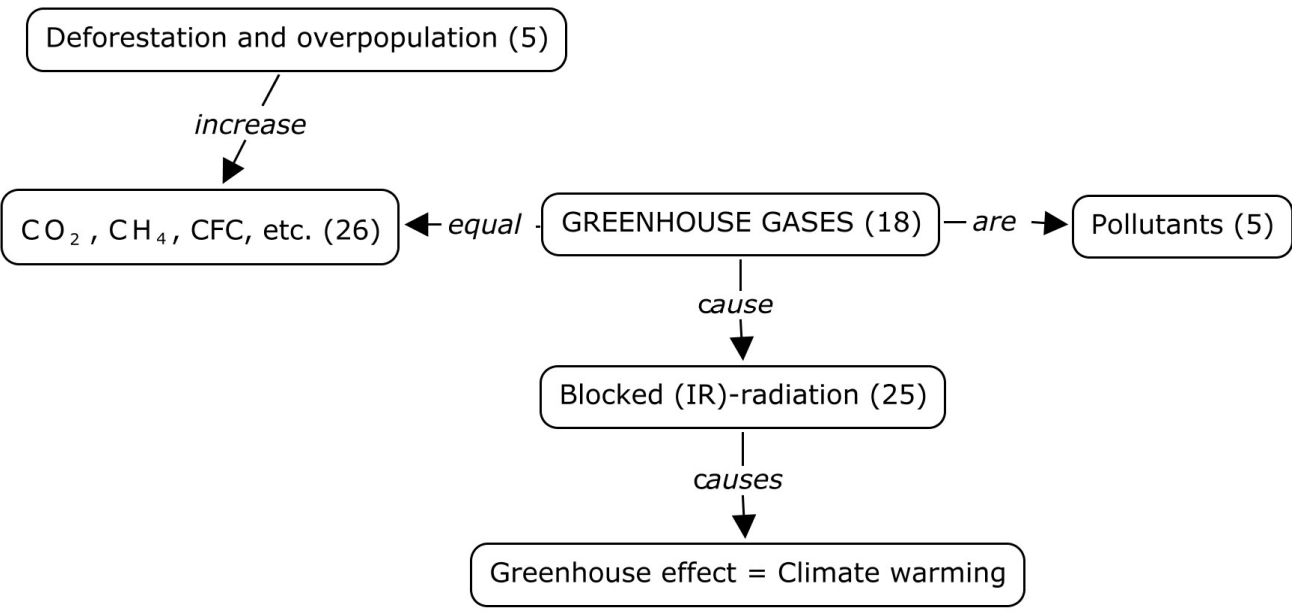

Figure 1. Greenhouse gases cause the greenhouse effect $(n=32)$. Number in parenthesis $=$ the number of students' mentions.

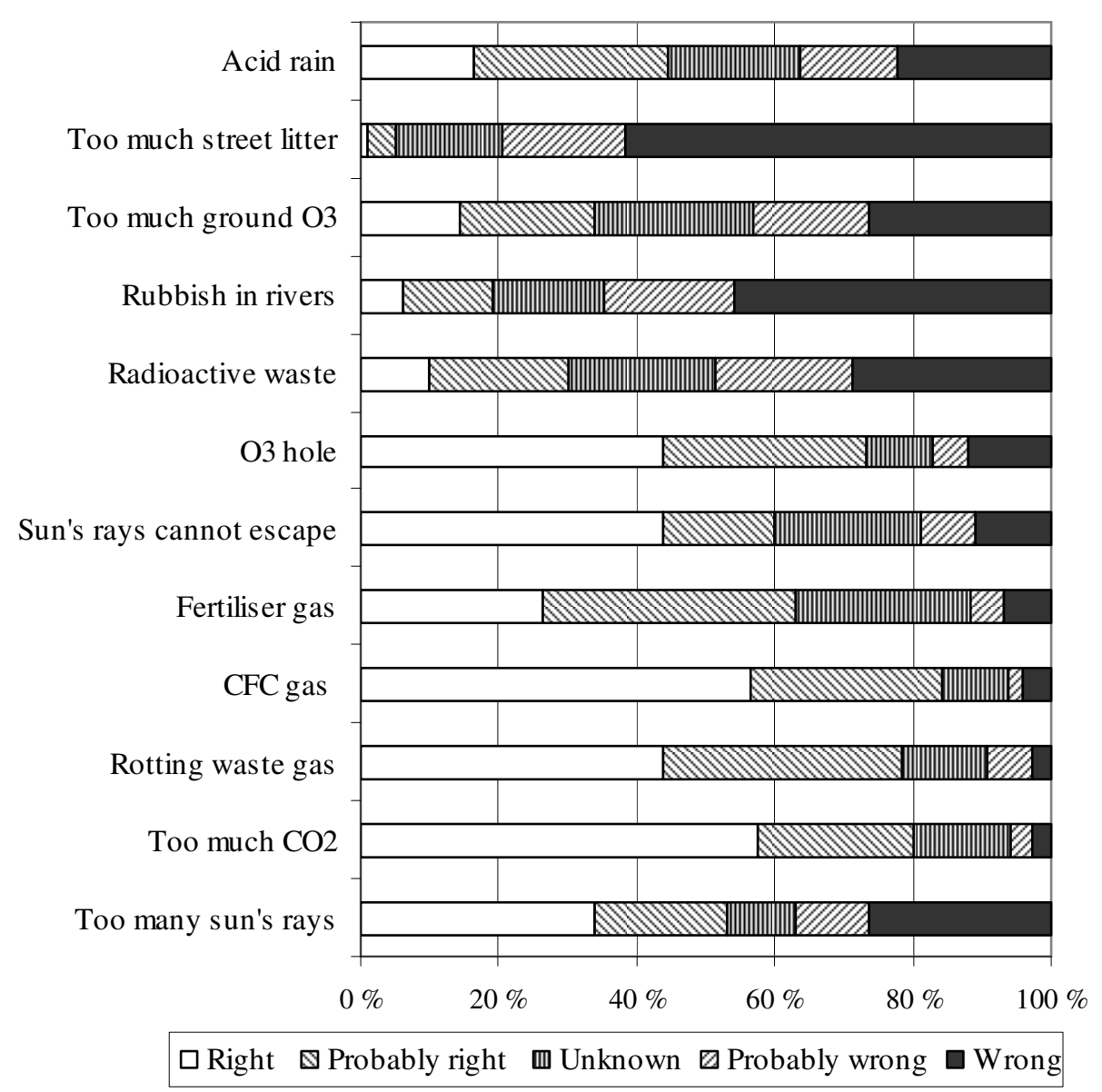

Figure 2. Distribution of students' responses on the causes of the greenhouse effect.

Conceptual Distinction that the Thinning Atmosphere is the Reason for the Greenhouse Effect. 


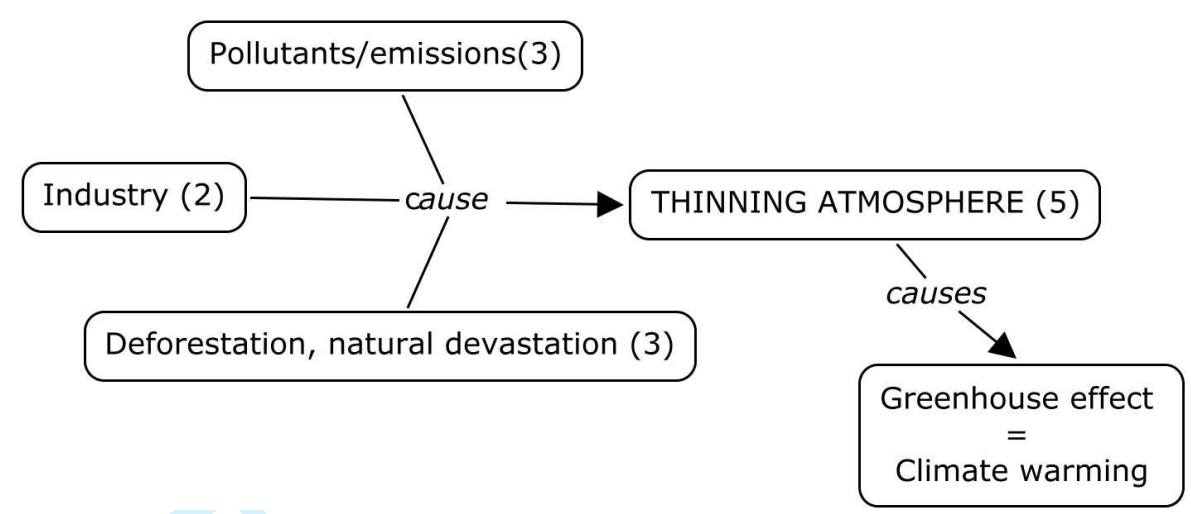

Figure 3. The thinning atmosphere causes the greenhouse effect $(n=5)$. Number in parenthesis $=$ the number of students' mentions.

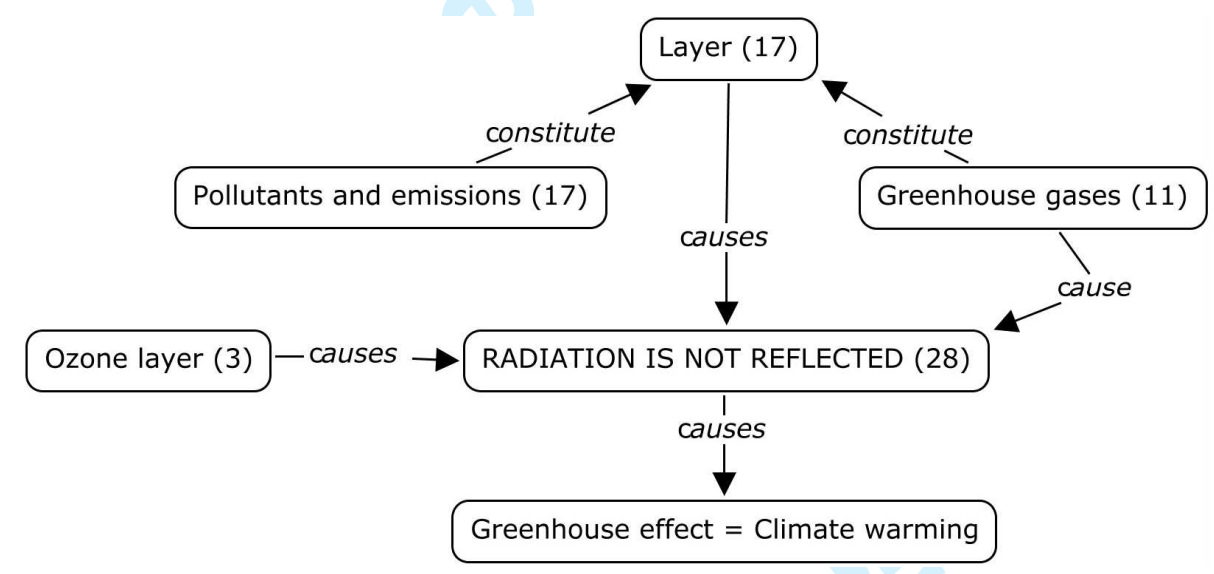

Figure 4. Disturbed radiative forcing causes the greenhouse effect $(n=28)$. Number in parenthesis $=$ the number of students' mentions. 


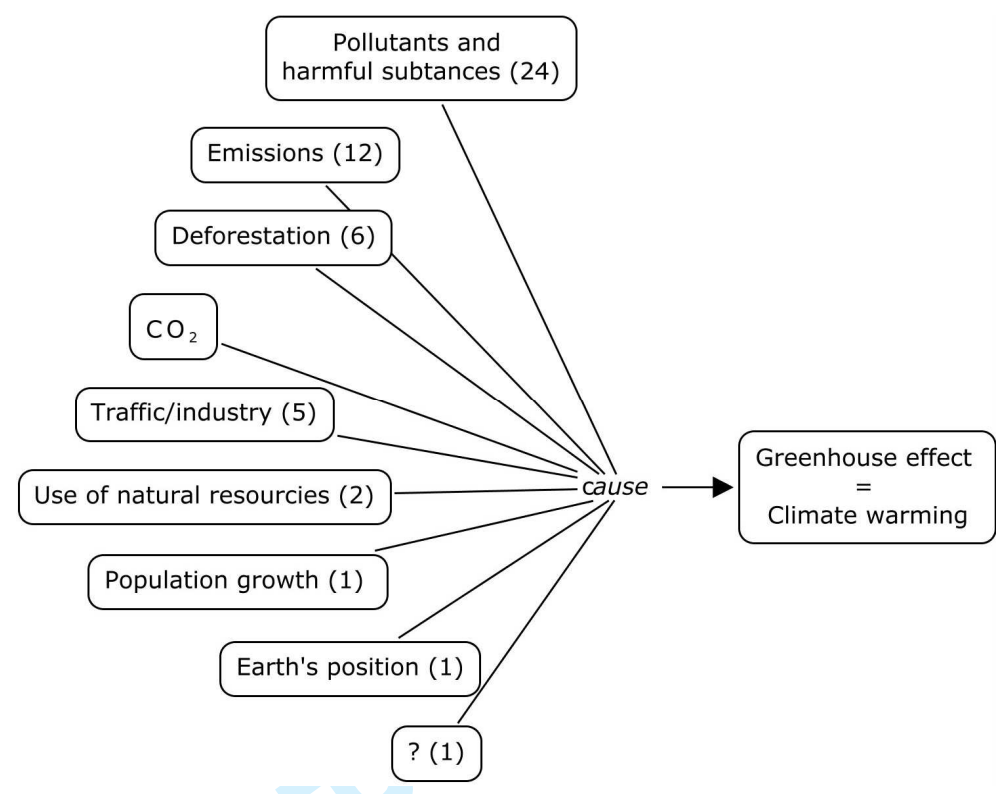

Figure 5. The simplified causal relationship of the greenhouse effect $(n=24)$. Number in parenthesis $=$ the number of students' mentions.

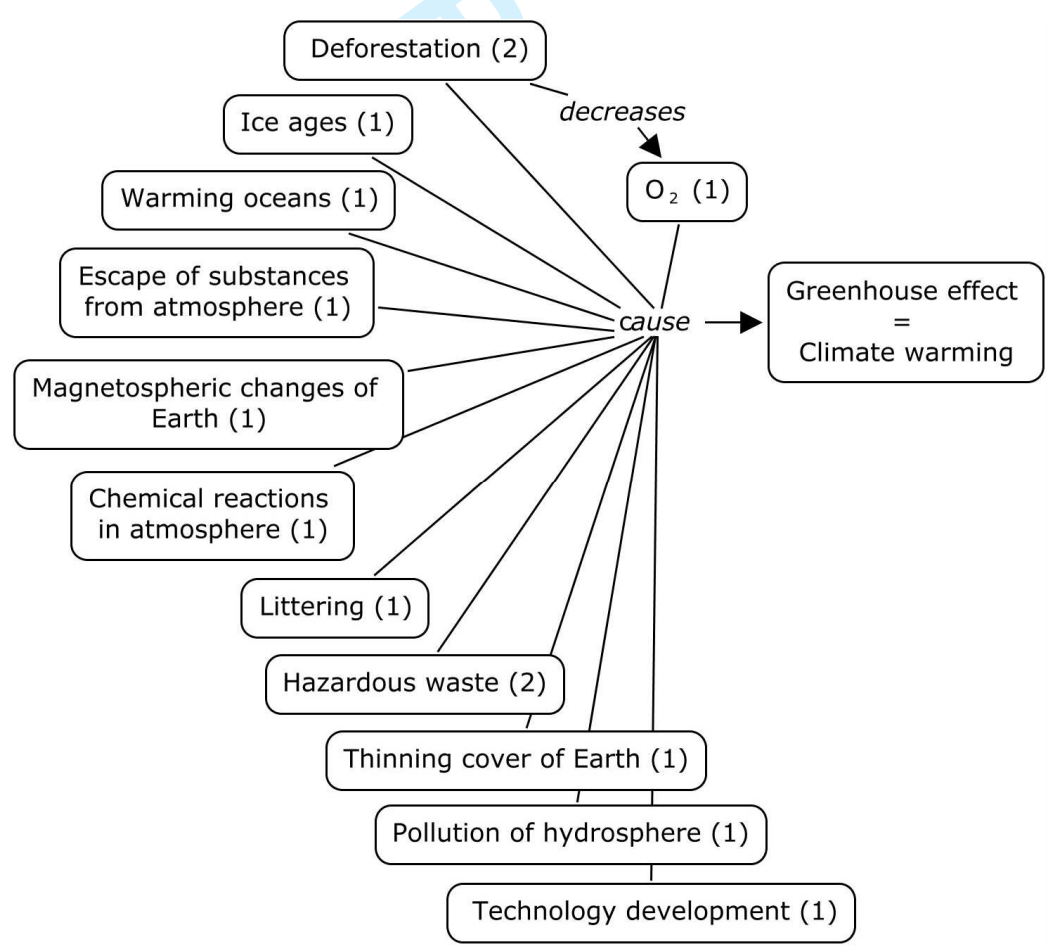

Figure 6. The illogical explanation of the greenhouse effect $(n=11)$. Number in parenthesis $=$ the number of students' mentions. 


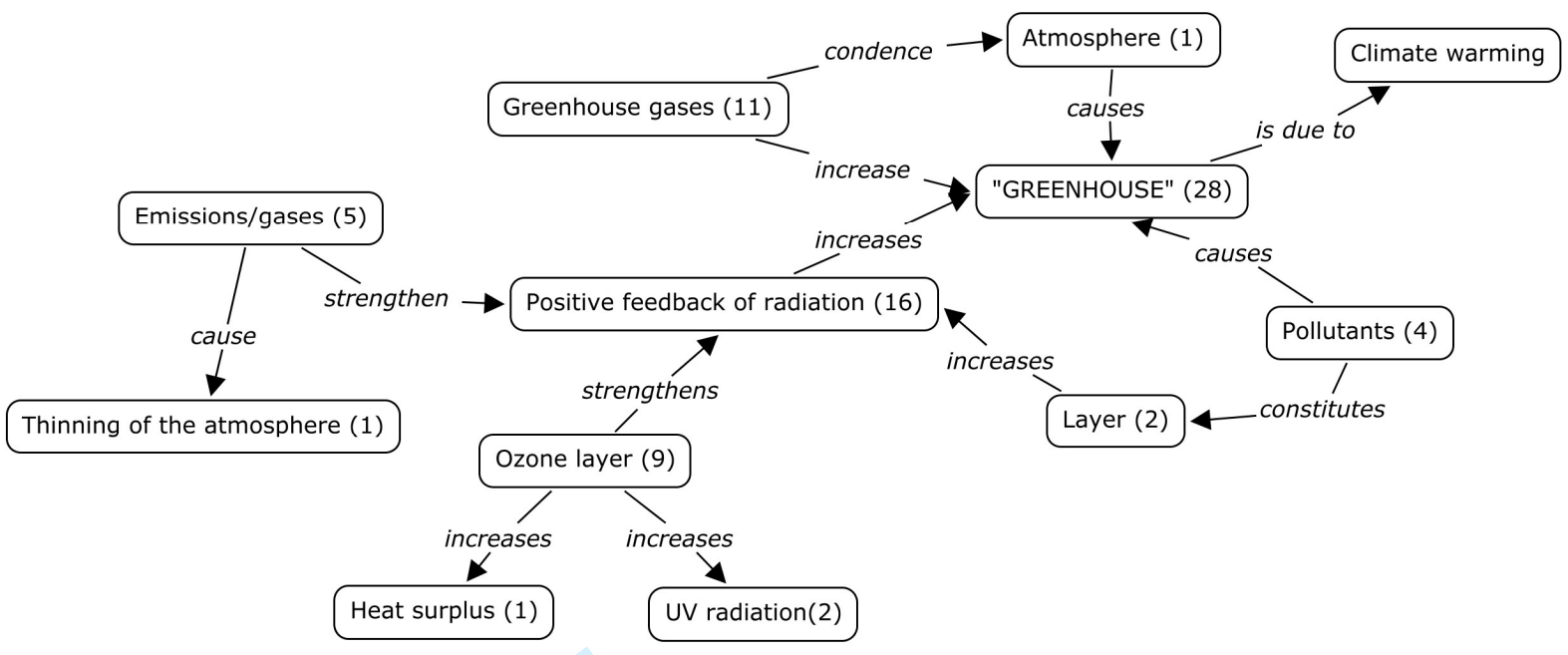

Figure 7. A greenhouse as an analogy for the greenhouse effect $(n=28)$. Number in parenthesis $=$ the number of students' mentions.

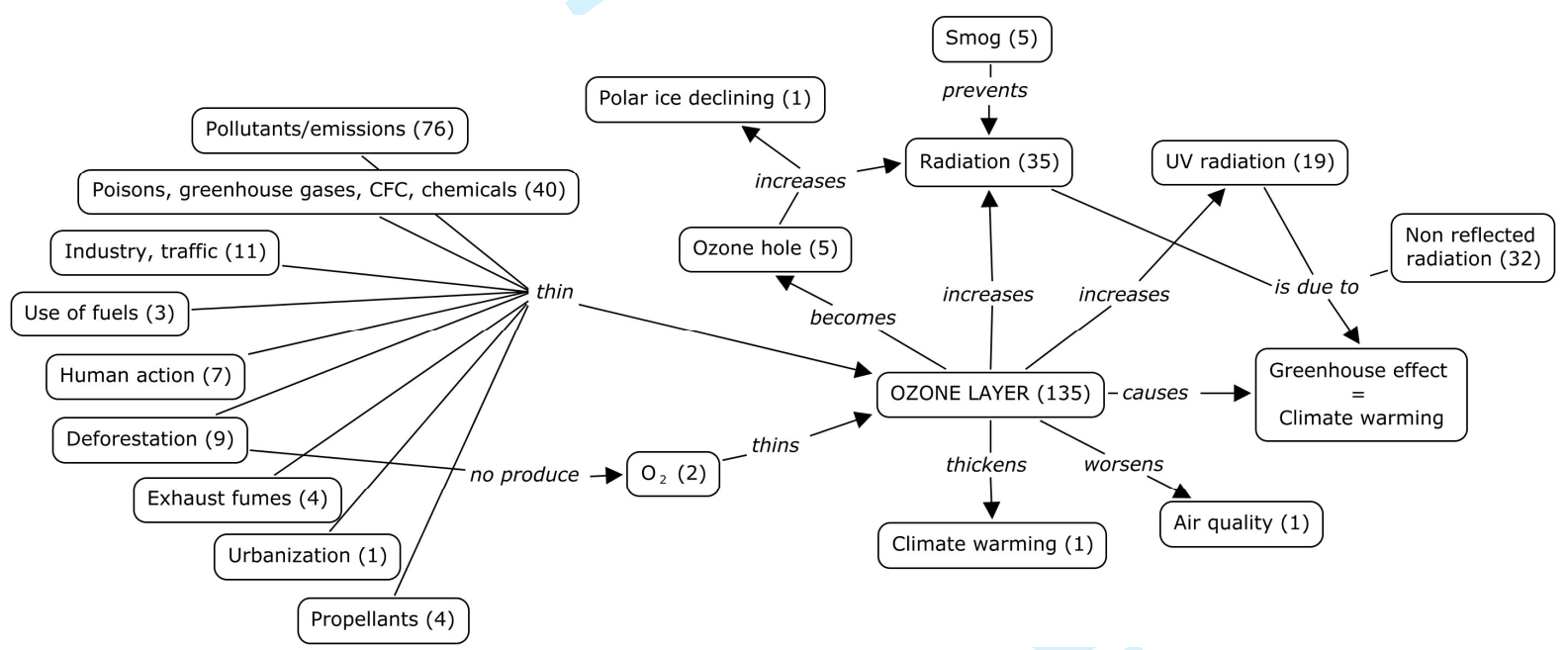

Figure 8. Ozone layer depletion is causally related to the greenhouse effect $(n=135)$. Number in parenthesis $=$ the number of students' mentions. 


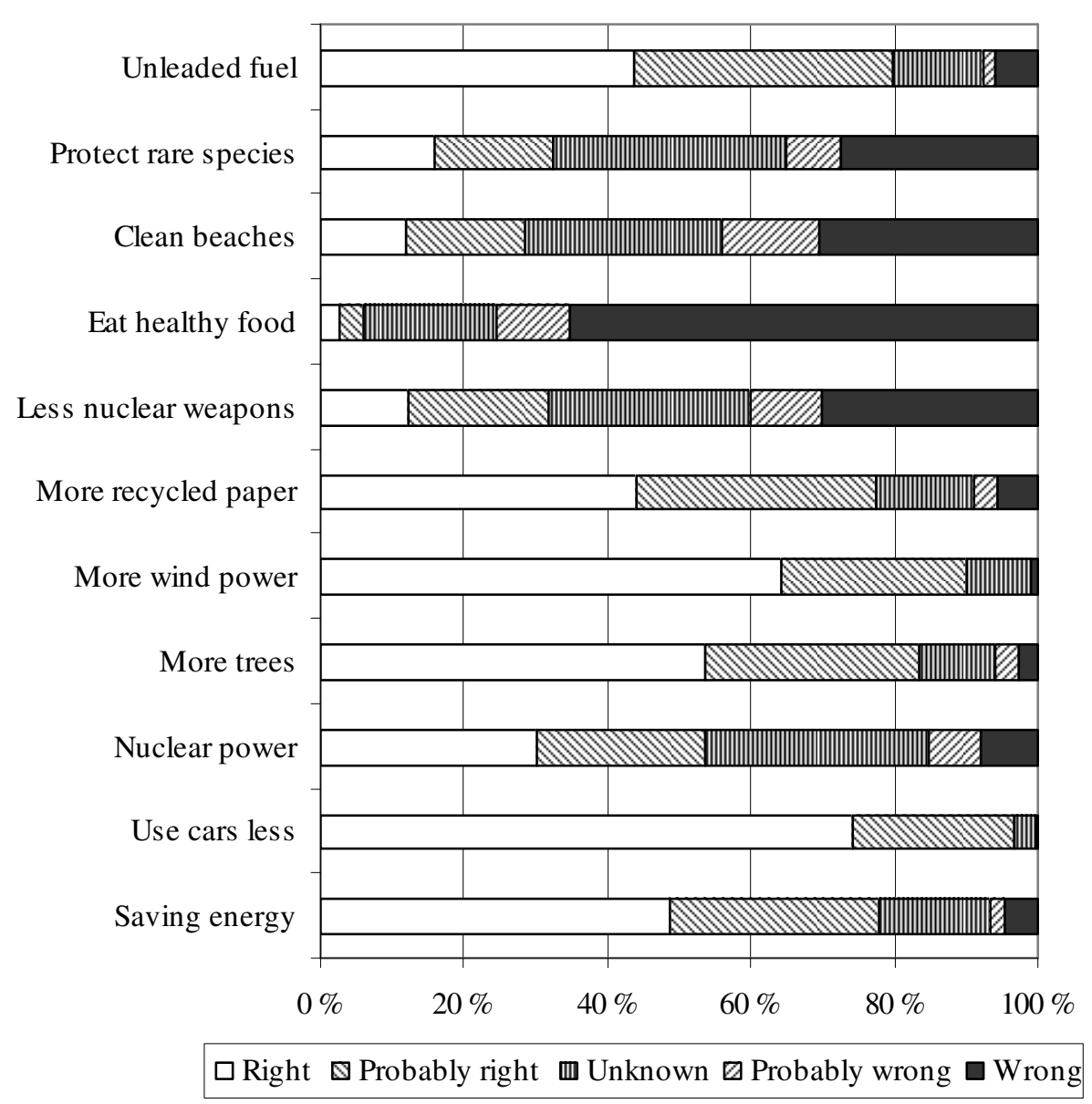

Figure 9. Distribution of students' responses about cures of the greenhouse effect $(n=275)$. 
Appendix 1. Simplified concept map related to the greenhouse effect. Boxes drawn by dash line depict some solutions for the mitigation of climate warming.

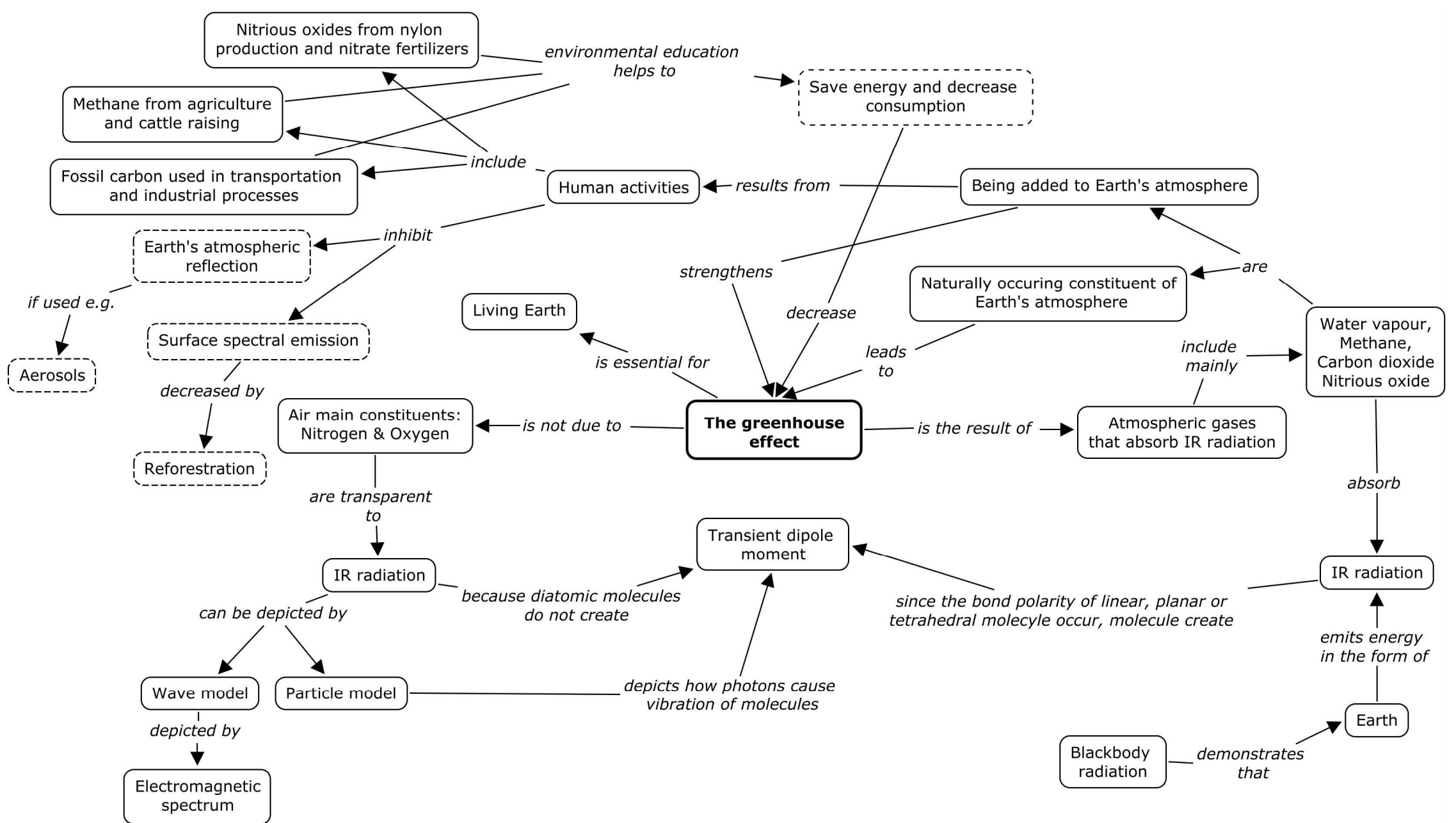

URL: http://mc.manuscriptcentral.com/tsed Email: ijse_editor@hotmail.co.uk 
Table 1. Students' conceptualizations of the greenhouse effect and climate change.

\begin{tabular}{ll}
\hline Conception & Research \\
\hline $\begin{array}{l}\text { Climate change is not understood as a } \\
\text { change of radiation balance. }\end{array}$ & Koulaidis \& Christidou, 1999; Anderson \\
& \& Wallin, 2000; Nevanpää, 2005
\end{tabular}

Climate change is causally related to Boyes \& Stanisstreet, 1997; Koulaidis \& ozone depletion. Christidou, 1999; Ekborg \& Areskoug, 2006; Jeffries, Stanisstreet, \& Boyes, 2001; Papadimitriou 2004; Nevanpää, 2005

Climate change is confused with other phenomena.

Boyes \& Stanisstreet, 1997; Anderson \& Wallin, 2000

Every environmentally harmful action Gowda, Fox, \& Magelky, 1997; Fisher, causes climate change. 1998; Papadimitriou, 2004; Nevanpää, 2005

Greenhouse gases are understood Fisher, 1998; Koulaidis \& Christidou, insufficiently. 1999; Anderson \& Wallin, 2000; Ekborg \& Areskoug, 2006; Papadimitriou, 2004

The influence of climate change on Fisher, 1998; Anderson \& Wallin, 2000; ecology and society is not understood. Nevanpää, 2005

Table 2. Respondents' background information.

\begin{tabular}{lcccc}
\hline Variable & Frequency & $\%$ & $M$ & $S D$ \\
\hline Respondents & 275 & - & - & - \\
Women & 217 & 79 & - & - \\
Men & 58 & 21 & - & - \\
Age & 275 & - & 23.80 & 4.48 \\
Matriculation examination mark & 275 & - & Magma \\
& & \multicolumn{3}{c}{ cum laude } \\
Geography mark & & - & approbatur \\
Biology mark & 270 & - & 8.74 & .82 \\
Physics mark & 275 & - & 8.58 & .93 \\
Chemistry mark & 258 & - & 8.03 & 1.28 \\
\hline
\end{tabular}


Table 3. Students' responses to the question If the greenhouse effect gets bigger... True $=$ Right + I think this is right, False $=\mathrm{I}$ think this is wrong $+\mathrm{I}$ am sure this is wrong. Non-scientific statements are italicised. Results given as percentages of all responses. $(n=275)$

\begin{tabular}{lcccc}
\hline & True & False & Be unknown & Total \\
\hline Earth will get hotter & 94 & 4 & 2 & 100 \\
More flooding & 94 & 2 & 4 & 100 \\
Changes in world's climate & 99.6 & 0 & .4 & 100 \\
More deserts & 77 & 8 & 15 & 100 \\
More crop diseases & 64 & 6 & 30 & 100 \\
Sea level will rise & 89 & 3 & 8 & 100 \\
Polar ice melting & 96 & 2 & 2 & 100 \\
Biodiversity will decrease & 77 & 5 & 18 & 100 \\
More hearth attacks & 16 & 50 & 34 & 100 \\
More food poisoning & 12 & 64 & 24 & 100 \\
More skin cancer & 79 & 10 & 11 & 100 \\
More river fish poisoned & 36 & 33 & 31 & 100 \\
More earthquakes & 25 & 44 & 31 & 100 \\
\hline
\end{tabular}

Table 4. Distribution of students' responses to questions on students' knowledge of the greenhouse effect and the assumed sources of that knowledge. Results given as percentages of all responses. ( $n$ $=275)$.

\begin{tabular}{lcccccc}
\hline & A lot & Something & A little & $\begin{array}{c}\text { Nothing at } \\
\text { all }\end{array}$ & $\begin{array}{c}\text { No } \\
\text { answer }\end{array}$ & Total \\
\hline I know & 10 & 58 & 30 & 1 & 1 & 100 \\
$\begin{array}{l}\text { Learnt from } \\
\text { school }\end{array}$ & 17 & 50 & 29 & 4 & 0 & 100 \\
$\begin{array}{l}\text { Learnt from TV } \\
\text { Learnt from radio }\end{array}$ & 9 & 45 & 33 & 13 & 0 & 100 \\
$\begin{array}{l}\text { Learnt from the } \\
\text { press }\end{array}$ & 8 & 46 & 36 & 91 & 2 & 100 \\
$\begin{array}{l}\text { Learnt from } \\
\text { studies }\end{array}$ & 10 & 37 & 31 & 21 & 1 & 100 \\
\hline
\end{tabular}


Table 5. Varimax rotated principal components calculated from the attitude statements and their variable loadings.

\begin{tabular}{lccc}
\hline Attitude statements & Pessimism & Protection & Techno \\
\hline $\begin{array}{l}\text { I cannot do much to prevent the } \\
\text { deteriorating state of the }\end{array}$ & .731 & \\
environment. \\
Ordinary people cannot affect & .600 & \\
the state of the environment. & & \\
I do not support protection of & .566 & \\
the environment if other people & & \\
do not protect it. \\
The state of the environment is & .549 & \\
so good that is not worth paying & & \\
attention to. \\
$\begin{array}{l}\text { People have to change their } \\
\text { lifestyle completely in order to }\end{array}$ \\
save nature. \\
$\begin{array}{l}\text { Nature would have to be } \\
\text { protected even if it does not }\end{array}$ \\
increase welfare. \\
I am ready to compromise my \\
own welfare for the better future \\
of the environment. \\
$\begin{array}{l}\text { Science and technology can } \\
\text { solve environmental problems. }\end{array}$ \\
A built landscape is more \\
beautiful than a natural \\
landscape.
\end{tabular}


Table 6. Varimax rotated principal components for students' responses to questionnaire items about possible consequences and cures of the greenhouse effect. Only loadings greater than .5 are shown.

\begin{tabular}{|c|c|c|c|c|}
\hline $\begin{array}{l}\text { Questionnaire } \\
\text { item }\end{array}$ & Awareness & Misconceptions & Consequences & Illness \\
\hline $\begin{array}{l}\text { If the greenhouse effect } \\
\text { gets bigger... }\end{array}$ & & & & \\
\hline ...more food poisoning & & & & .648 \\
\hline ...more heart attacks & & & & .554 \\
\hline ...more fish poisoned & & & & .548 \\
\hline ...polar ice melts & & & .696 & \\
\hline ...more sea level rise & & & .606 & \\
\hline $\begin{array}{l}\text {...more changes in world's } \\
\text { climate }\end{array}$ & & & .515 & \\
\hline $\begin{array}{l}\text { The greenhouse effect can } \\
\text { be smaller... }\end{array}$ & & & & \\
\hline ...keep beaches clean & & .664 & & \\
\hline ...fewer nuclear bombs & & .650 & & \\
\hline ...protecting rare species & & .577 & & \\
\hline ...more wind power & .735 & & & \\
\hline ...more trees & .649 & & & \\
\hline ...using recycled paper & .647 & & & \\
\hline ...saving energy & .614 & & & \\
\hline ...not using cars so much & .504 & & & \\
\hline ...more nuclear power & .503 & & & \\
\hline Eigenvalue & 4.066 & 2.715 & 1.472 & 1.359 \\
\hline Exp. of total variance $\%$ & 17 & 11 & 6 & 6 \\
\hline
\end{tabular}

